Scandinavian Journal of Management (2009) 25, 85-96

\title{
Discursive (de)legitimation of a contested Finnish greenfield investment project in Latin America
}

Maria Joutsenvirta

Helsinki School of Economics, PB 1210, FI-00101 Helsinki, Finland

\author{
Eero Vaara
}

HANKEN School of Economics, PB 479, FI-00101 Helsinki, Finland

EMLYON Business School, France 


\begin{abstract}
Despite the central role of legitimacy in corporate social responsibility debate, little is known of subtle meaning-making processes through which social actors attempt to establish or deestablish legitimacy for socially contested corporate undertakings, and through which they, at the same time, struggle to define the proper social role and responsibility of corporations. We investigated these processes in the context of the intense socio-political conflict around the Finnish forest industry company Metsa“-Botnia's world-scale pulp mill in Uruguay. A critical discursive analysis of Finnish media texts highlights three types of struggle that characterized the media coverage: legalistic argumentation, truth fights, and political battles. Interestingly, this case illustrates how the corporate representatives - with the help of the national media - tend to frame the issue in legalistic terms, emphasize their expert knowledge in technical and environmental evaluations, and distance themselves from political disputes. We argue that similar tendencies are likely to characterize corporate social responsibility debates more generally..
\end{abstract}

KEYWORDS: Corporate social responsibility; Legitimacy; Discourse; Media; Multinational corporation; Forest industry

\title{
Introduction
}

Growing global concerns about ecological and social problems such as climate change, poverty and depletion of natural resources together with increasing expectations that corporations take more responsibility for the well-being of people and nature have intensified academic debate within the field of business and society. In this paper, we aim to extend the discussion about legitimacy among corporate social responsibility (CSR) scholars as well as to contribute to the discursive theorizing about legitimacy more generally. In spite of the central role of legitimacy in CSR debate (e.g., Deegan, 2002; Palazzo \& Scherer, 2006; Sethi, 1975; Wood, 1991), little is known of subtle meaning-making processes through which various actors attempt to establish or de-establish legitimacy for socially contested corporate operations and through which they, at the same time,participate in defining the proper social role and responsibility of corporations. Indeed, the narrow conception of legitimacy in the CSR debate has prevented both researchers and practitioners from gaining an understanding of some crucial sociopolitical processes involved in the legitimation of contested corporate undertakings. 
Our starting point is that a central part of building social acceptability (i.e., legitimacy) for controversial corporate actions takes place through argumentation. We argue that a discursive perspective on legitimacy carries the potential to avoid some of the shortcomings of earlier legitimacy theorizing around CSR (Palazzo \& Scherer, 2006). In particular, it allows us to understand the complexities, ambiguities and contradictions around legitimation (Vaara \& Tienari, 2008).

In this paper, we provide a discursive analysis of a revealing case that illustrates some of the societal and political tensions produced by multinational corporations' (MNC) investments in technology and capital hungry countries (Sethi, 2002). The Finnish forest industry company Metsa“- Botnia's (henceforth Botnia) world-scale pulp mill project in the Uruguayan town of Fray Bentos, situated on the banks of the Uruguay River that forms the boundary between Uruguay and Argentina, sparked harsh criticism and opposition from Argentinean civil activists. Organized demonstrations against Botnia have mobilized tens of thousands of Argentineans, particularly residents and neighbours of the town of Gualeguaychu ' on the opposite bank of the Uruguay River, whose tourism has been seen to be endangered by the potential pollution of the pulp mill into the river. In the open and widely mediatized conflict, the activists have criticized Botnia's project by referring to its potential negative impacts on the environment and people's health as well as towards the local economy and culture. Having started as a civil reaction against the pulp mill projects of the Spanish ENCE and Botnia, the conflict has widened into an intense diplomatic dispute between Argentina and Uruguay, which has both been affected by and had negative impacts on Botnia. Our research question is: Through which discursive strategies do various actors construct a sense of (il)legitimacy in sociopolitical conflicts involving firms? The study focuses on media texts seeing them as an increasingly important arena where corporate activities are legitimized and delegitimized.

Our analysis of Finnish media texts uncovers three types of discursive legitimation struggle which characterize the media coverage: legalistic struggles, truth struggles, and political struggles. In particular, this case illustrates how the corporate representatives - with the help of the national media - tend to frame the contested corporate undertaking in legalistic terms, emphasize their expert knowledge in technical and environmental evaluations, and distance themselves from political disputes. We discuss some implicit consequences of these discursive (de)legitimation acts in relation to the social role of 
corporations in a global society. Our analysis also makes visible aspects which problematize Botnia's legitimating attempts and provide us interesting manifestations of the politicization of corporations, an increasingly discussed phenomenon in the current CSR debate (e.g., Matten \& Crane, 2005; Matten, Crane \& Chapple, 2003; Palazzo \& Scherer, 2006; Scherer \& Palazzo, 2007). We argue that similar tendencies are likely to characterize debates around corporate social responsibility more generally.

We begin with a brief overview of the CSR literature by focusing on the prevailing conception of legitimacy and its shortcomings. We then present a discursive perspective on legitimacy which is useful in uncovering crucial and often ignored sociopolitical processes involved in the legitimation of contested MNC undertakings. In the following two sections, we describe the empirical context of our study as well as the data and the method of analysis. We then present the three types of legitimation struggle. The final section summarizes the issues raised in the article and discusses the implications of the study for theory and practice.

\section{Legitimacy in corporate social responsibility literature}

The notion of legitimacy is an important theme in sociological analysis in general (Berger \& Luckmann, 1966; Giddens, 1984; Parsons, 1960; Weber, 1968) and organizational analysis in particular (Deephouse \& Suchman, 2008; DiMaggio \& Powell, 1983; Dowling \& Pfeffer, 1975; Meyer \& Rowan, 1977; Scott, 1995; Suchman, 1995). While there are different approaches to legitimacy, most subscribe to a view where it is defined as "a generalized perception or assumption that the actions of an entity are desirable, proper or appropriate within some socially constructed system of norms, values, beliefs, and definitions" (Suchman, 1995, p. 574).

The fundamental assumption of legitimacy theory is "the idea that in order to continue operating successfully, corporations must act within the bounds of what society identifies as socially acceptable behaviour' (O'Donovan, 2002, p. 344). Therefore, it is not surprising that legitimacy has become an important avenue for CSR theorizing. According to Wood (1991), "the basic idea of corporate social responsibility is that business and society are interwoven rather than distinct entities; therefore, society has certain expectations for appropriate business behavior and outcomes' (p. 695). In her often cited CSR taxonomy, legitimacy is the key concept at the institutional (or societal) level of analysis, as opposed to the organizational and individual levels. Palazzo and Scherer (2006) have claimed that the 
core assumption of various concepts through which scholars have theorized about the role of corporations in society (CSR, corporate citizenship, business ethics, stakeholder theory and the like) is "the unavoidability of normative conformity with the social environment", and, therefore, legitimacy “is the 'yardstick' of the discussion in the CSR field”' (p. 73; see also Sethi, 1975, p. 60).

Legitimacy provides us an important way of thinking about the threat that the powerful reaction from civil activists or other societal actors cause for controversial corporate undertakings. Indeed, growing direct pressure from civil society on corporations (e.g., Sethi, 2002) together with changing power relations between state, economy, and civil society groups (e.g., Margolis \& Walsh, 2003; Marsden, 2000; Matten \& Crane, 2005) have changed the societal limits to profit making, and legitimacy has become a critical issue for corporations, especially for globally operating multinationals (Palazzo \& Scherer, 2006).

Legitimacy theory has been an often used framework to explain how various corporate ethical practices (standards, codes, programs, policies, etc.) can serve to legitimize corporate operations (e.g., Bansal \& Roth, 2000; De Blasio, 2007; Deegan, 2002; Hunter \& Bansal, 2007; Long \& Driscoll, 2008). Much of the CSR literature that has applied legitimacy theory originates from the area of social and environmental accounting. These scholars have used the theory especially to explain why corporations inform publicly about their social and environmental performance (Deegan, 2002). They have explored the purpose of and motivations for corporate environmental and social disclosures and suggested that compa- 86 M. Joutsenvirta, E. Vaara nies must communicate their ecological and social concerns in order to establish, maintain or repair various forms of legitimacy (Campbell, 2000; Deegan, Rankin, \& Tobin, 2002; Milne \& Patten, 2002; O’Donovan, 2002; O’Dwyer, 2002; Patten, 1992). Environmental and social disclosures and other information on corporate web sites have been the major data source to study the relationship between legitimacy and corporate ethical activities, and content analysis has been an often used method of analysis. However, there are studies that have also utilized other data such as interviews and multistakeholder meetings (e.g., Driscoll, 2006; O’Donovan, 2002; O’Dwyer, 2002). Methods that focus on language use have sometimes been used as a complementary method (e.g., Driscoll, 2006; Long \& Driscoll, 2008).

Though useful, earlier legitimacy analyses around CSR have tended to marginalize aspects of legitimacy which we see as increasingly crucial. First of all, in line with the 
general tendency of current CSR theorizing to approach organizational legitimacy (Palazzo \& Scherer, 2006), legitimacy analyses have usually considered legitimacy as a resource on which corporations are dependent for survival and that they often can manipulate or impact (Dowling \& Pfeffer, 1975; Pfeffer \& Salancik, 1978) through ethical codes, standards, policies and other ethical activities. This literature often seeks 'best practices' that would be applicable if not universally, at least in many different legitimacy-ascribing environments. Unfortunately, these studies have, at the same time, marginalized sensitivity to the social and cultural embeddedness of the acts of (de)legitimation. In so doing, they have also downplayed the dynamic, controversial and complex sociopolitical aspects and processes involved in the (de)legitimation acts themselves.

Moreover, earlier legitimacy analyses around CSR have tended to emphasize retrospective rather than prospective CSR communication between a corporation and its stakeholders. It is assumed that through corporate disclosures and other strategies managers can successfully react to perceived legitimacy gaps and respond to the changing perceptions of relevant publics. However, recent discussions about CSR have emphasized the growing need for a prospective sense of responsibility and more democratic forms of communication between business and society (see e.g., Calton \& Payne, 2003; Morsing \& Schultz, 2006; Palazzo \& Scherer, 2006; Swanson, 1999).

It has been argued that a central theoretical dilemma of the current CSR debate stems from instrumental interpretations of CSR and its thin concept of corporate legitimacy (Palazzo \& Scherer, 2006; Scherer \& Palazzo, 2007). In the background of legitimacy analyses around CSR has generally been the idea that corporations use various strategies and policies to conform with or alter social perceptions, expectations, or values as part of a legitimation process (O’Donovan, 2002, p. 345; see also Dowling \& Pfeffer, 1975). By utilizing the strategic approach to legitimacy it is assumed that managers can actively shape the way in which various stakeholders view the firm (Bansal \& Clelland, 2004, p. 95). Through the institutional approach, on the other hand, it is thought that corporations should aim to conform with societal expectations and values (DiMaggio \& Powell, 1983; Dowling \& Pfeffer, 1975).

Palazzo and Scherer (2006; Scherer \& Palazzo, 2007) have recently argued convincingly that in today's postnational and pluralistic society both of these assumptions are increasingly problematic. Following Suchman (1995), they expect that moral concerns prove 
resistant to corporations' self-interested efforts to influence individuals' calculations and to persuade key stakeholders (Palazzo \& Scherer, 2006, p. 72- 73). Moreover, the on-going processes of individualization, the devaluation of tradition, and the globalization of society are resulting in a loss of cultural homogeneity. Referring to Kostova and Zaheer (1999), they claim that the general assumption that corporate legitimacy is based on conformity with societal rules is very problematic. In a heterogeneous global society, the corporate environment consists of a multiplicity of often contradictory norms from a wide range of institutional and cultural environments in the different host countries. Therefore, questions relating to the relationship between business and society are of a much higher level of complexity than in traditional national contexts (Scherer \& Palazzo, 2007, p. 1108), and the legitimacy-ascribing environment of multinationals is much more heterogeneous than in the pre-globalization age (Palazzo \& Scherer, 2006, p. 77).

Palazzo and Scherer (2006) propose a fundamental shift " from an output and power oriented approach to an input related and discursive concept of legitimacy" (p. 71). They place the idea of corporate acceptance into the communicative network of public debate and argue that legitimacy should be considered less as something to be engineered, manipulated, bought or imitated by organizations and more as a result of communication where the societal limits to profit making are continuously defined and redefined.

We suggest that a discursive perspective (e.g., Fairclough, 1992; Potter \& Wetherell, 1987; Silverman, 1993; Van Dijk, 1993) on legitimacy carries the potential to avoid some of the shortcomings of earlier legitimacy theorizing around CSR, and it allows both ethically sensitive and pragmatic CSR theorizing (for the evaluation of different schools of thought of CSR, see Scherer \& Palazzo, 2007). Instead of being based on instrumental understanding of CSR and its thin conception of legitimacy, discursive perspective is sensitive to the fact that societal norms and values, as well as the boundaries of socially acceptable corporate behavior, are culturally and historically bound and constantly under social contest and change. These are often neglected but increasingly crucial aspects in aiming to understand not just legitimacy challenges but also other aspects regarding contested MNC undertakings in an increasingly interconnected global society (e.g., Levy, 2008; Scherer, Palazzo, \& Baumann, 2006). In the next section, we provide a theoretical and methodological basis for applying a discursive approach to study legitimacy in the context of CSR.

\section{Discursive perspective on legitimacy}


Despite the considerable amount of attention devoted to legitimacy (e.g., Ashforth \& Gibbs, 1990; Deephouse, 1996; Dowling \& Pfeffer, 1975; Hybels, 1995; Kostova \& Zaheer, 1999; Ruef \& Scott, 1998; Suchman, 1995), only recently has this literature started to pay serious attention to the discursive aspects and to the processual understanding of legitimacy as an outcome of a continuous social and discursive contest (e.g., Creed, Scully, \& Austin, 2002; Lawrence, Phillips, \& Hardy, 1999; Phillips, Lawrence, \& Hardy, 2004; Suddaby \& Greenwood, 2005; Vaara \& Tienari, 2008). Impor- Discursive (de)legitimation of a contested Finnish greenfield investment project in Latin America 87 tantly for our purpose, these aspects of legitimacy have also started to raise scholarly interest in the context of sustainable development (e.g., Coupland, 2005, 2006; Livesey, 2001, 2002).

However, few systematic analyses have been conducted on the discursive practices through which various actors attempt to establish or de-establish legitimacy for contested corporate undertakings and through which they, at the same time, participate in defining the proper social role of corporations in a global economy. In our analysis, we examine legitimation as discursive processes that construct the social phenomena under study. Accordingly, we focus on discursive practices which do not simply represent but also constitute social reality. Thus, we assume that people do not use language just to make accurate representations of certain objects but, rather, to accomplish things (e.g., Alvesson \& Ka“rreman, 2000; Potter \& Wetherell, 1987). A discursive perspective allows us to shift attention from "established senses of legitimacy to ongoing discursive struggles for legitimation and, thus, increases our understanding of the microlevel political dynamics of these processes"' (Vaara \& Tienari, 2008, p. 988). From a discursive perspective, it is the situated speech acts in which a specific corporate undertaking is questioned or justified that are considered "moments of (de)legitimation"' (see Hybels, 1995, p. 245). Both the criticism (acts of delegitimation) and the defensive responses to the critique (acts of (re)legitimation) are largely discursive and hence in need of detailed discursive analysis (Rojo \& Van Dijk, 1997).

By applying a discursive approach we see legitimacy as constructed primarily through discursive resources (Suddaby\& Greenwood, 2005), i.e., through linguistic means used to construct some aspect of reality froma particular perspective. Therefore, rather than attempting to understand through which policies and actions firms try to establish or maintain their legitimacy regarding CSR, we seek to investigate through which discursive strategies various actors construct a sense of (il)legitimacy (Vaara, Tienari,\&Laurila, 2006). Thus, our 
study approaches corporate social responsibility as a culturally and historically situated dialogical activity in which managers and other actors jointly define rules for socially acceptable business behavior through conversations.

Following recent discursive legitimacy analyses around contested MNC undertakings (Vaara \& Tienari, 2008; Vaara et al., 2006) our study draws from critical discourse analysis (CDA) whose central interest in broader social practices and power relations is able to link legitimation "to ongoing political struggles in specific organizational and societal contexts" (Vaara \& Tienari, 2008, p. 986). By adopting a CDA approach originally introduced by Norman Fairclough (1992), our analysis focuses on 'talk' which is used to legitimize or delegitimize a controversial corporate undertaking. This talk is treated as

"an active, reflexive, interpretative and collaborative process of representing the world while simultaneously negotiating social relations with others and one's own identity, as one moment in a social practice. It is an open process in which new representations, social relations and social identities may emerge, and in which outcomes are unintended and unpredictable - but only to an extent', (Chouliaraki \& Fairclough, 1999, pp. 46-47).

Fairclough (1995b) sees people's language use through three dimensions that connect "features of texts, ways in which texts are put together and interpreted, and the nature of the social practice'' (p. 74). Language use not only produces objects but also discursive identities (subjectivities) for speakers and others. A critical stance to language use is furthered by paying attention also to how language use produces relationships of power and helps to sustain social relations based on domination. The representational, relational and identificational processes of language use take place simultaneously, and they are part of a practical engagement with the world. (Chouliaraki \& Fairclough, 1999; Fairclough, 1992, 2005). Language is thus seen as a form of social behavior that is in dialectic interaction with other social spheres.

The above leads us to formulate our research question as follows: Through which discursive strategies do various actors construct a sense of (il)legitimacy in sociopolitical conflicts involving firms? Next, we provide a short description of our case.

\section{The Botnia case}


In February 2005, Botnia received permission to build a gigantic million-ton eucalyptus pulp mill worth nearly one billion euros in the small Uruguayan town of Fray Bentos, situated on the banks of the Uruguay River, which forms the boundary between Uruguay and Argentina. It is the biggest industrial private sector investment by Finland abroad and the largest industrial investment in Uruguay's history. One of the factors that influenced in Botnia's decision to build the plant in Uruguay was that it was considered a very politically stable nation. However, the greenfield investment project has not only caused a large-scale civil reaction in Argentina but also an intense diplomatic dispute between the two Latin American states.

Tens of thousands of Argentineans, in particular residents and neighbours of the town of Gualeguaychu' - on the opposite bank of the Uruguay River — have held demonstrations against Botnia claiming that its pulp mill would pollute the river, risk people's health and endanger the area's tourism. The target of the criticism has not only been Botnia but also the Spanish ENCE with its own plans to build a pulp mill in Uruguay. In September 2006, ENCE withdrew from the original location, Fray Bentos, and decided to move its mill out of the Uruguay River. In Uruguay, the government and political opposition as well as most citizens have supported Botnia's project, but in Argentina it has been opposed by the president, the government, the majority of citizens and various activist groups. The blockings of the roads and bridges between Uruguay and Argentina by protestors, especially those of a local group called Asemblea Ambiental (Environmental Assembly), has had negative impacts on tourism and other transportation which has angered Uruguay. Since the first mass protests started in April 2005, the conflict has widened into a serious and multifaceted diplomatic dispute between Uruguay and Argentina, which also affects the Finnish government. While Finnish representatives have emphasized that Finland as a state is not a party to the dispute, Argentina sees Finland as directly involved. 88 M. Joutsenvirta, E. Vaara

The intense conflict around Botnia's pulp mill illustrates well some of the societal and political tensions produced by corporate investments in technology and capital hungry countries (Sethi, 2002). In the context of our analysis, a critical incident took place in the middle of March 2006 when the presidents of Argentina, Ne'stor Kirchner, and of Uruguay, Tabare' Va'zquez, announced their joint decision to try to suspend the construction of the pulp mills for 90 days and to abolish the road blocks to facilitate the negotiations between the two countries. The following day, Tabare' Va'zquez denied the contract, and Botnia said it 
would continue constructing the mill. At the beginning of April, Botnia announced it would suspend the construction for 10 days "as a gesture of good will" to contribute to the opening of dialogue between Argentina and Uruguay. The length of the suspension did not satisfy Argentina, and the planned negotiations were cancelled.

At that stage, the World Bank refrained, for the time being, from granting Botnia's investment project a loan and a guarantee against political risk. The EU Commissioner of Trade gave his support to Botnia and stated that the conflict may hinder further European investments in the two Latin American countries. At the end of April, the Finnish Minister for Foreign Trade and Development visited Uruguay but cancelled her planned visit to Argentina saying that she does not want to become "a pawn in the game', She announced that the Finnish government could not participate in the dispute since the investment is a private undertaking.

In May 2006, the government of Argentina took the dispute to the International Court of Justice (ICJ) in The Hague, accusing Uruguay of violating the bilateral Treaty of the Uruguay River regarding the conservation of the river. In July, the court in its temporary judgment rejected Argentina's request for an injunction to stop the construction of the plants. In November 2006, theWorld Bank approved financing worth USD 170 million and a guarantee for up to USD 350 million for Botnia's pulp mill in Fray Bentos. In January 2007, ICJ rejected Uruguay's request for "provisional measures", against Argentina aimed at putting an immediate end to blockades of bridges and roads.

On November 2007, the Uruguayan government gave final approval to produce eucalyptus pulp at Botnia's mill, and on November 15, the mill produced its first load. The ecological, social and economic impact studies and Botnia's assurances have not stopped the criticisms towards the mill, and angry mass demonstrations against the plant have continued.

\section{Data and analytic method}

Earlier studies on discursive legitimating practices of corporations in relation to CSR have utilized, in particular, corporate materials such as environmental and social reports (e.g., Coupland, 2005; Livesey, 2002; Livesey \& Kearins, 2002; Tregidga \& Milne, 2006). The data of our study consists of media articles that were collected from Helsingin Sanomat, the leading Finnish daily newspaper and an opinion leader in the Finnish media. In our view media provides an increasingly important and underutilized context for studying discursive 
legitimation of controversial corporate undertakings (see also Alvarez, Mazza, \& Pedersen, 2005; Vaara et al., 2006). However, there are also other reasons for our choice of data.

First, in a global mediatized society, corporations are - more than ever before embedded in open public debates which have become an increasingly important legitimating arena for them, especially in situations in which corporate actions are publicly criticized. Botnia's Latin American dispute is to a great extent a "mediatized conflict" which has received extensive media interest and exposure. Since our interest is in discursive and political processes of (de)legitimation, media texts offer us a particularly fruitful study context. The efforts to (de)legitimize the pulp mill are taken to a great degree in public and by utilizing public awareness of the issues. When writing press releases or being interviewed by journalists, the representatives of Botnia and other actors target their talk to media audiences, in this case the Finnish public. For our purposes, the ways in which various actors try to (de)legitimize the project by appealing to the general public are, therefore, particularly relevant. Second, when exploring societal contradictions and changes, media texts represent significant material because of their particular sensitivity to these processes. Societal changes which are often provisional, incomplete and disordered in nature tend to manifest themselves in the contradictions of media texts (Fairclough, 1995a). Third, since journalistic practices tend to play with multiple perspectives and contrasting rationalities and moralities (Vaara et al., 2006, p. 805), media texts are likely to include arguments from both opponents and proponents of Botnia's project. Therefore, they will provide us access to both legitimation and delegitimation acts in different stages of the conflict.

By utilizing the electronic archive of Helsingin Sanomat, we collected all articles that contained the words 'Botnia' and 'Uruguay' covering the period from 1 January 2005 to 15 May 2007. The total number of articles was 102, nearly half of which were published during the first six months of the year 2006. This data set was divided into the following four time periods with their corresponding number of articles: 14 (2005); 49 (1 January-30 June 2006); 20 (1 July_31 December 2006); 19 (1 January-15 May 2007). The crucial period for the purposes of this study turned out to be the first 12 months after the first Helsingin Sanomat news article was published about the conflict between Argentina and Uruguay in August 2005. It was during this one-year period that the statements by Botnia's management and communication department as well as various supporters and opponents of the project had a particularly significant role in the Finnish media debate. After the summer of 2006, the 
conflict lost some of its news value in Finland, and the comments by Botnia and other actors became scarce in the articles.

We carefully selected those articles that were built around various parties' opinions about the conflict. The articles that focused on reporting 'hard facts' about Botnia's pulp mill or describing issues not pertaining to the conflict (e.g., informing about suppliers or financing of the project), for their part, did not represent material of primary interest. A total of 27 articles were eventually chosen for a detailed and systematic analysis. ${ }^{1}$ The arguments that Botnia's managers presented to the public to defend and justify the Discursive (de)legitimation of a contested Finnish greenfield investment project in Latin America 89 investment project were of particular interest, and it was' them that the journalists of Helsingin Sanomat most often cited during the early phases of the conflict. However, other actors' 'voices' (Fairclough, 1995b) were included in the analysis which allowed us to make inter-actor comparisons and study both legitimating and delegitimating attempts.

In our data reading, we focused on identifying discursive strategies used in each particular (de)legitimating act regarding Botnia's project. The systematic analysis of language used by journalists would make an interesting contribution to the discursive legitimation literature in itself, but our immediate concern was language used by Botnia and various supporters and opponents of its investment project. However, it is important to emphasize that the media have had a crucial role to play in the production of the discursive legitimation struggles reported below. It is the journalists who have interviewed various parties of the conflict and read their press releases; it is the journalists who have written the articles and included the direct statements of their sources in them, detaching this '(de)legitimation talk' from the original (interview, press release) context, etc. Therefore, the legitimation struggles identified by this study have been co-produced by the journalists and the parties of the conflict.

Our analysis proceeded as follows. We first identified and collected together all the text fragments that we saw as representing acts of discursive (de)legitimation. The total number of these text fragments was 74. In line with the study by Vaara et al. (2006),

\footnotetext{
${ }^{1}$ Discourse analysis generally uses small data sets because the objective of the analysis is to say 'a lot about little' and because the analysis is particularly laborious and time-consuming (Potter \& Wetherell, 1987, pp. 161-162; Silverman, 1993, p. 3).
} 
frequency and strategic importance were used as the main criteria when identifying discursive (de)legitimation patterns. In the interdiscursive (e.g., Fairclough, 1995b) phase of the analysis, we focused on different kinds of linguistic means used for framing the contested corporate undertaking and for establishing or de-establishing legitimacy for it. We distinguished three discourses through which Botnia, journalists and various proponents and opponents of Botnia's pulp mill repeatedly attempted to legitimize or delegitimize the project. Table 1 describes the three discourses and shows the frequency of their occurrence in our total set of discursive (de)legitimation acts. In many (de)legitimation acts, some discourses overlapped, which is typical in CDA analyses.

Based on these three discourses, and in order to emphasize their socially contested nature (e.g., Livesey, 2001, 2002), we were able to distinguish and elaborate on three types of discursive struggle: legalistic struggles, truth fights, and political battles. 
Table 1. Characterizations and frequency of the three (de)legitimating discourses

\begin{tabular}{|l|l|c|}
\hline Discourses & Characterization of discourse & $\begin{array}{l}\text { Frequency of occurrence } \\
\text { (in absolute numbers and in } \\
\text { percentages) N=74 }\end{array}$ \\
\hline Legal discourse & $\begin{array}{l}\text { (De)legitimizes Botnia's project by } \\
\text { referring to laws and generally applied } \\
\text { rules and standards. }\end{array}$ & $24(32 \%)$ \\
\hline $\begin{array}{l}\text { Factual } \\
\text { discourse }\end{array}$ & $\begin{array}{l}\text { (De)legitimizes Botnia's project by } \\
\text { referring to factual, usually science- } \\
\text { based, information about the } \\
\text { ecological and social impacts of the } \\
\text { mill. }\end{array}$ & \begin{tabular}{|c} 
(22 \\
(De)legitimizes Botnia's project by \\
referring to the political or a-political \\
role of the company in the dispute.
\end{tabular} \\
\hline Political \\
discourse
\end{tabular}

\section{Discursive (de)legitimation of Botnia's pulp mill in Latin America}

\section{Legalistic struggles}

Earlier literature has discussed how corporations often respond to public criticism by claiming that they abide by laws and generally applied standards. In fact, legal responses have been considered as one central means through which organizations tend to justify their actions when confronted with a charge of wrongdoing (Ashforth \& Gibbs, 1990; Basu \& Palazzo, 2008; Sethi, 2002; Spar \& La Mure, 2003). However, few studies have analyzed what we can call 'legalistic legitimation attempts' in detail and in relation to the potential or actualized counter-claims. Our analysis demonstrated that not only the proponents but also the opponents of Botnia's pulp mill as well as the Finnish journalists attempted to (de)establish legitimacy for the contested project by emphasizing the (il)legality of the actions taken. See, for example, the following excerpts:

According to Varis (the CEO of Botnia, addition by authors) there is not enough substance for Argentina to take the issue to the international court of justice. "It is bickering between two countries.” . . . All the licenses are valid, and Uruguay's government wants us to continue,'’ says Varis (24 August 2005) 
According to Erkki Varis the construction of the mill will continue. According to him the construction work cannot be stopped by legal means because the construction licenses are in order. . . Piilonen (the head of Uruguay operations for Botnia, addition by authors) says that Metsa“-Botnia is now waiting for an official statement by Uruguay on the matter at hand. (13 March 2006)

In the Finnish media debate, legalistic arguments were used as an important means through which the discussants contested and negotiated the legitimacy of Botnia's pulp mill. It is reasonable to assume that these contests were intensified by the fact that the project was seen to be subordinated to several rule-making bodies.

While Botnia's legality claims typically rested on the licenses and notices received from Uruguay's government, those of the opponents referred to the international treaty for the administration of the uses of the Uruguay River. In 1975, Argentina and Uruguay had jointly established the administrative commission of the Uruguay River (Comisio'n Administradora del R1'o Uruguay) in order to guarantee the optimal and rational utilization of the river. This was a perspective that Greenpeace promoted in the media:

According to Greenpeace, Botnia's construction work is illegal because the commission responsible for the control of the Uruguay River has not accepted the project and the study about the impacts of the mill. ... Piilonen denies Greenpeace's claim that the construction work is illegal. "Everything we do is hundred per cent legal. We have all of the permits from Uruguay, which is a sovereign state." (18 January 2006)

It is noteworthy that legalistic arguments were particularly strong and common in Botnia's defensive statements. This observation gives reason to assume that the legal framework formed a particularly tempting basis for Botnia's attempts to legitimize its Latin American investment project and delegitimize the problematic criticism by the opponents. Moreover, and interestingly, not only the proponents and opponents of the project but also the Finnish journalists actively took the legality of Botnia's actions as a central aspect through which they discussed and evaluated the dispute in the Finnish public debate.

As for the social role of corporations, legalistic struggles pictured governments, government officials and courts of justice as the actors with the most power in the conflict. At 
the same time, they marginalized the role and the influence of MNCs in assessing potential ecological and social harms caused by the project. The role of corporations was to follow well-institutionalized norms and the rules made by public policy makers. Legalistic struggles were thus implicitly based on the traditional division of labor between business and government and produced corporations as obedient subordinates of governments and various law-making institutions.

\section{Truth struggles}

Not surprisingly, and in accordance with earlier studies on environmental debates (e.g., Joutsenvirta, in press; Mirvis, 2000; Yearley, 1991), the protagonists and antagonists also employed factual discourse, which assumes that the investment project should be judged rationally based on objective facts rather than subjective interests, values, opinions and the like. Objective facts typically meant information provided by scientific research and experts. Given the complexity of the environmental impact assessment and prevailing disagreements about least harmful practices used in the pulp production, the media coverage was frequently characterized by 'truth fights' about the environmental impact. The following are typical examples of such arguments:

"I doubt anybody has read it (the environmental report of the mill, addition by authors) in Argentina, and the general public does not have any knowledge about this industry. And if it does, it is based on the old industry', says Varis (11 August 2005)

In its press release, Greenpeace disapproves of the fact that Botnia will, without further reasoning, bleach the pulp in Uruguay with the controversial ECF (elemental chlorine free, addition by authors) method, which involves the use of toxic chlorine dioxide. Consequently, the effluents of the mill will include, for example, ecologically harmful chlorine phenols and carcinogenic dioxins, assesses the organization. The conception about dioxides is based on a study conducted at the University of Stockholm last year. (18 January 2006)

Now the plan is to study the issue (impacts of the mill, addition by authors) by forming a committee to which Argentina will name three and Uruguay three experts. According to Varis the result will not change, "because the facts are the same as before". "We have said that we are ready for anything and that we will give all the 
necessary information. Studies can be done during the construction work since the mill will not start running until the fall of 2007. So, go ahead.’' (13 March 2006)

As for the social role of the corporation, truth struggles pictured Botnia as a rational decision-maker who relies on 'hard objective facts.' This role was manifested particularly strongly by Botnia's legitimation acts which explicitly juxtapose 'objective facts' with 'political' or 'principled' opinions:

The CEO of Metsa"-Botnia, Erkki Varis, thinks that the demands are political and they are not based on scientific or technical facts. According to him, the work continues as planned. (11 August 2005)

"I am waiting that the central government in Buenos Aires would start using reason and looking at the project not just from a political viewpoint. Our problem is that these issues are not simple to explain', says Piilonen (24 December 2005)

According to Piilonen, ECF bleaching has not been found to be harmful for the environment. ... “This is Greenpeace's expression of faith in chlorine-free bleaching instead of accepting scientific facts'’. (18 January 2006)

Intimations or explicit descriptions of irrationality of the critical opponents were used as a means to undermine the critics and, thus, establish legitimacy for the actions taken by Botnia. This kind of legitimating act is not uncommon among corporations whose undertakings are publicly criticized (see e.g., Coupland, 2005; Joutsenvirta, 2006, in press).

In the modern information-oriented society, the reliance on reason and expert knowledge may seem a natural basis for justifying contested business operations and establishing legitimacy for them. However, and paradoxically, while Botnia's legitimation attempts repeatedly privileged factual, science-based and technical knowledge, in many accounts the reliance on objective information is constructed as not being able to establish social acceptance (legitimacy) for the project. This 'fact' is produced, either directly or indirectly, as a problem for Botnia. 
Metsa"-Botnia has received "clean papers" from the World Bank for the construction of a pulp mill in Uruguay. The bank thinks that the effluents into water and emissions into the air are so minor that at least ecological issues are not an obstacle for getting finance. Metsa"-Botnia does not believe that the report will end the Argentinean demonstrations against the project. "They would be satisfied Discursive (de)legitimation of a contested Finnish greenfield investment project in Latin America 91 only with a recommendation that the mill can not be built', says Timo Piilonen (24 December 2005)

Studies have been done, and stakeholders have been heard in both Argentina and Uruguay. Botnia has not been able to control Argentinean opinions. "The only way is to give right information. But giving information out there is difficult, and opinions do not change overnight." (the head of Uruguay operations for Botnia, addition by authors) (25 February 2006)

"We respect the people of the area and we know that they have fears and concerns. However, we are not able to get our message through in Gualeguaychu'. We would like to tell the residents of the area that they have nothing to worry about. . . True, we are used to them (accusations from Argentineans, addition by authors) and we are ready to give answers and discuss with them. The opposition is not based on lack of information, as they claim, but lack of will." (Botnia's Vice President of Communications, addition by authors) (30 August 2006)

These accounts point to certain shortcomings of truth struggles and their underlying faith in objectivity. According to Calton and Payne (2003), corporate reliance on modern science and expert knowledge does hold out the promise of prediction and control of processes linked to controversial corporate actions. However, this reliance simultaneously tends to 'silence' dissent and marginalize important political, moral and philosophical issues involved in those processes (pp. 14-15). Interestingly, one such issue was 'spoken out' by the Finnish Ambassador to Argentina and Uruguay who saw Botnia's and its allies' technorational assurances as suffering from a credibility problem that is rooted in deep cultural values and beliefs. Her description of the problem implicitly produced a North-South division which is characterized by an unequal and unjust power relationship: 
"Trust in officials and institutions here is traditionally weak, and suspicions run deep. The belief that foreign companies can come here and use old technology which has been banned in Europe, lives strong', Jolkkonen says.' (13 March 2006)

Despite these ambiguities and uncertainties, neither the representatives of Botnia nor Finnish journalists questioned the central role of expert knowledge in technical and environmental evaluations in the contest. Let us next take a look at the third type of discursive struggle through which the legitimacy of Botnia's project was repeatedly contested in the Finnish media.

\section{Political struggles}

The changing division of labor between the public and private sectors is an increasingly discussed phenomenon in the CSR literature (e.g., Matten \& Crane, 2005; Palazzo \& Scherer, 2006; Scherer \& Palazzo, 2007). While legalistic struggles reproduced the traditional division of responsibilities between business and government, political struggles took this same division into the center of attention and contest: they focused on the attempts by the discussants to establish (de)legitimacy for Botnia's project by trying to argue that contested issues (do not) belong to the domain of business as opposed to government. Through these attempts, the conflict became an 'ideological battle' in which protagonists and antagonists promoted their interests and respective worldviews.

During the conflict, Botnia repeatedly stated that it was not a participant in the political conflict between Argentina and Uruguay and could not, thus, take part in the negotiations between the countries. Consider, for example, the following statements in Helsingin Sanomat between the summer of 2005 and winter 2006:

"We try to give the right information, but we cannot get involved in foreign politics.

It is unfortunate that this has become a conflict between these countries. But I still do not see that it will prevent the project from continuing'” says Varis (11 August 2005)

"It is a matter for the countries themselves how to agree on the matter", comments Piilonen (18 January 2006)

In these excerpts, Botnia's managers constructed the dispute about the mill as a source and a product of a regional political conflict between Uruguay and Argentina. The speakers 
argued in a way that distanced the company from being a party of the dispute that had arisen between the two countries because of the pulp mill. In doing so, they were visibly sustaining the apolitical nature and role of corporations and reproducing the traditional division of responsibilities between business and government.

The way managers distanced Botnia from the conflict also had an impact on who was seen as possessing the power to solve the problems. In the above excerpts, this power was assigned to the governments of the two countries while Botnia was depicted as an outsider without power to influence the solution. The conflict was reproduced as an external political risk connected to the foreign direct investment project and an event outside the horizon of the actions of the company. From the point of view of CSR, these discursive patterns provided a vehicle for the company not only to distance itself from the dispute at hand but also from potential 'extra' responsibilities involved in the construction of the pulp mill.

The most striking example of reproduction of Botnia as apolitical actor in our data is the following account in which the European Commissioner of Trade aimed to establish legitimacy for Botnia's project in Uruguay:

Peter Mandelson gives strong backing to Metsä-Botnia in the dispute between Uruguay and Argentina over the construction of a pulp mill at the border between the countries. According to Mandelson, Botnia is "an innocent victim" in the conflict. ... "It is an international dispute between two sovereign states. It is unreasonable for a European company to be caught in the middle, especially when such a large investment is involved." . . "I am disappointed that the dispute has continued for so long. The company is an innocent victim in the middle of disagreements between two countries. If the dispute is not soon resolved, the difficulties could jeopardize future European investments in both countries.'” (24 April 2006)

What is of particular interest is the metaphorically powerful way of reframing Botnia's role in the conflict through the 92 M. Joutsenvirta, E. Vaara words " an innocent victim." This linguistic act included attempts to position the company as an outsider and a completely powerless party in the conflict between the two countries. Moreover, the words "innocent" and "victim" created a sensation that the two Latin American countries are unfairly mistreating this European company which has not committed any wrongdoing. The 
account of the EU Commissioner of Trade can be seen to represent the most extreme position regarding the apolitical nature of Botnia.

Interestingly, the accounts of the representatives of the Uruguayan and Argentinean governments produced a strikingly different kind of social role for Botnia:

According to the Uruguayan government the planned meeting for this week between the presidents of Uruguay and Argentina is cancelled because of the attitude of Botnia. Argentina which is opposing the pulp mill has stated as a condition for the meeting that the construction work will be suspended for 90 days. The chief of the cabinet of the Uruguayan government, Gonzalo Fernandez, said in the press conference held in Montevideo that the government of the country is very sorry that Botnia has not understood the real scale and dimension of the conflict. (6 April 2006)

The Minister of Foreign Affairs of Argentina, Jorge Taiana, accused Botnia for the failure of the contract .. when the Minister of Internal Affairs of Argentina, Anibal Fernandez, criticized Vazquez for lack of authority. "Kirchner should negotiate with Botnia instead of Vazquez to solve the conflict. Kircher and Botnia's management seem to be the only ones that have authority" . . . He called the ten day suspension "almost a joke"'. "The decision shows that there is no chance that the government of Uruguay will suspend the contstruction work. If Va'zquez does not have power even to suspend the construction work, would he have power to suspend the factories if they pollute?', (12 April 2006)

These excerpts not only created an active role for Botnia in the dispute that had arisen between Uruguay and Argentina but a central one. Botnia was depicted as a powerful party in the battle of interests and one that should take an active role to help find a solution between the countries. It is also noteworthy that both of the above statements took a critical view of Botnia's project — even the one by the Uruguayan government that had been one of the main supporters of the project.

There is another interesting observation regarding the political struggles. While Botnia's early statements tended to picture the company not as an agent of, but rather as a subject to, the dispute between Argentina and Uruguay, several of Botnia's later accounts seemed to implicitly contradict those legitimation acts. Our analysis uncovered how Botnia's apolitical identity implicitly broke down in the company's own legitimation attempts. The 
following accounts authored by Botnia's CEO do not picture the company as completely apolitical. Instead, Botnia is depicted as actively — although resistantly — engaging in the battle of interest promotion, and the role of the corporation is implicitly politicized.

Erkki Varis does not understand why the presidents of Uruguay and Argentina cannot meet to solve the disputes regarding the pulp mill project in Fray Bentos. Botnia has been accused for its attitude that has prevented the presidents from negotiating. "The guilty party must always be found. If it has to be us, so be it', says Varis. . . . According to Varis Uruguay has still not presented its official request regarding the suspension of the construction work. Botnia suspended the work at the mill on Friday for ten days without any legal obligation to do so. "This is our way to come in half way in the dispute', says Varis (8 April 2006)

“Argentina can wait for our gestures but we have given enough gestures already', the CEO of Metsa"-Botnia, Erkki Varis, says regarding the pulp contest between Uruguay and Argentina. Metsa“-Botnia will restart the construction work on Tuesday after Easter . . . The project was suspended for ten days so that the presidents of Argentina and Uruguay could try to solve the crisis. The suspension was a so called "gesture of a good will' from the Finns. ... "We told them in March that, very well, we will not start installing work during 90 days', says Varis (April 13, 2006)

Thus, like Shell's 'sustainability talk' (Livesey, 2002), Botnia's accounts were implicitly speaking more radically than the company's explicit statements. A subtle ambivalence in the political role and identity produced for Botnia in its own legitimation attempts seems to deconstruct the apolitical nature of corporations that Botnia and, for example, Finnish and EU officials have explicitly supported. The identity produced for the company in its representatives' language use includes not just a more active role in the conflict but also considerable influence in solving the conflict.

Political struggles thus reflected both Botnia's resistance to taking an active role in the regional political conflict caused by its investment project and a change towards a more explicit engagement in political processes around the pulp mill. This ambivalence can be seen to be part of the ongoing sociopolitical struggle regarding the social role and responsibility of business in the global economy (Livesey, 2001, 2002). Botnia's legitimation attempts that were based on the traditional apolitical role and identity of corporations did not seem to be 
able to guarantee social acceptability for its operations. Instead, the social and political pressures around its heavily contested investment project appeared to force the company to arguments that implicitly and somewhat ironically politicized its own identity.

\section{Summary and discussion}

We began by suggesting that previous CSR research has not focused adequate attention on the discursive aspects of legitimation in the context of controversial issues.We argued for a discursive perspective on legitimacy to overcome some of the shortcomings of earlier legitimacy analyses and to explore crucial dynamic, contradictory and socio-political processes involved in the legitimation of contested corporate undertakings. Our empirical inquiry focused on the Finnish media debate around the Finnish forest industry company Botnia's controversial pulp mill in Uruguay. Our aim was to investigate discursive strategies through which various actors constructed a sense of (il)legitimacy in socio-political Discursive (de)legitimation of a contested Finnish greenfield investment project in Latin America 93 conflicts involving firms. By utilizing a form of critical discourse analysis, we identified three types of discursive struggle through which protagonist and antagonists attempted to (de)legitimize the widely contested greenfield project. These struggles are summarized in Table 2.

Table 2. Discursive legitimation struggles around Botnia's FDI in Uruguay

\begin{tabular}{|l|l|l|l|}
\hline \multicolumn{1}{|c|}{$\begin{array}{c}\text { Discursive } \\
\text { legitimation } \\
\text { struggles }\end{array}$} & \multicolumn{1}{|c|}{$\begin{array}{c}\text { Focus of (de)legitimizing } \\
\text { rhetorics }\end{array}$} & \multicolumn{1}{|c|}{$\begin{array}{c}\text { Holders of } \\
\text { power }\end{array}$} & $\begin{array}{c}\text { Social role of } \\
\text { business }\end{array}$ \\
\hline $\begin{array}{l}\text { Legalistic } \\
\text { struggle }\end{array}$ & $\begin{array}{l}\text { Attempts to convince that corporate } \\
\text { actions are (il)legal }\end{array}$ & $\begin{array}{l}\text { Authorities, } \\
\text { jurisdiction }\end{array}$ & $\begin{array}{l}\text { Law and rule } \\
\text { abider }\end{array}$ \\
\hline Truth fight & $\begin{array}{l}\text { Attempts to convince that corporate } \\
\text { actions are (not) based on generally } \\
\text { accepted knowledge }\end{array}$ & $\begin{array}{l}\text { Experts, } \\
\text { scientists }\end{array}$ & $\begin{array}{l}\text { Rational } \\
\text { decision maker }\end{array}$ \\
\hline $\begin{array}{l}\text { Politico- } \\
\text { ideological } \\
\text { struggle }\end{array}$ & $\begin{array}{l}\text { Attempts to convince that contested } \\
\text { issues (do not) belong to the area of } \\
\text { business as opposed to government }\end{array}$ & $\begin{array}{l}\text { Governments, } \\
\text { MNCs }\end{array}$ & $\begin{array}{l}\text { A-political or } \\
\text { political actor }\end{array}$ \\
\hline
\end{tabular}


Our case illustrates how the corporate representatives - with the help of the national media - tended to frame the contested corporate undertaking in legalistic terms, emphasize their expert knowledge in technical and environmental evaluations, and distance themselves from political disputes. From the perspective of critical discourse analysis, the protagonists and antagonists were all engaged in ideological work (Fairclough, 1992, 1995a). As they strived to establish (de)legitimacy for the contested project, they simultaneously reconstructed the roles and responsibilities of corporations in the global economy. Crucial in this contest was how the speakers were able to connect their definitions to generally accepted values and norms.

Our analysis made visible aspects that questioned the efficiency of Botnia's legitimating attempts. From a broader critical perspective, legalistic and truth struggles are interesting in the sense that they subscribe to specific taken-for-granted "truths" about the social role of corporations. For example, Bauman and May (2001) have argued that legalrational legitimation "separates action from value choice and hence appears to render it valuefree. The executors of a command need not scrutinize the morality of the action they have been ordered to perform, nor do they need to feel responsible if the action fails a moral test." (p. 67). Truth struggles which assume experts' privilege to control knowledge, for their part, are based on charismatic legitimation and the conviction that someone has a privileged access to truth. According to Bauman and May, both of these legitimation types remove the values which the actions serve from the sight of the actors and render the action value-free and exempt from moral judgement. "The actors are offered . . escape from the burden of their freedom, which always comes complete with the responsibility for one's actions"' (p. $67)$.

Media texts, rather than actors' accounts, provided a crucial and underutilized channel to subtle social change processes that tend to be incomplete and disordered in nature (Fairclough, 1995a). Adding to earlier findings about corporate sustainability rhetoric (e.g., Livesey, 2001, 2002), a crucial change process was identified and analyzed in which the traditional division of responsibilities between business and government breaks down. Interestingly, the way in which protagonists and antagonists - through political struggles negotiated Botnia's political role and identity in the conflict can be seen as a manifestation of the 'politicization of the corporation'. This politicization is an important part of the redefinition of the roles and responsibilities of corporations (Matten \& Crane, 2005; Scherer 
\& Palazzo, 2007). Given the increasing engagement of MNCs in controversial operations, it is reasonable to assume that these kinds of legitimacy struggle will become even more accentuated in the future.

Our analysis also has practical relevance. Clearly, there is an increasing need for MNCs and their managers to estimate the scope of justifications and ethical considerations including also potential material and financial repercussions - of controversial operations to secure 'a social license' from critical stakeholders. For example, when Nokia's decision to relocate their mobile phone production from the German town of Bochum to Romania turned out to be unexpectedly damaging, Nokia's representatives admitted that they had been naive in underestimating the resistance in Germany. They also emphasized the importance of providing better justifications for its future international operations (Williamson, 2008). We believe that through this study, scholars and practitioners are better equipped to understand the subtle transformative processes that are unavoidably taking place in business-society relationship and that strongly affect corporations' ability to get social licenses for their actions. We argue that the tendencies that we identified in attempts to legitimize or delegitimize Botnia's pulp mill in Latin America are likely to characterize corporate social responsibility debates more generally.

Finally, while we have focused primarily on Botnia's communications, it is important to note that the media texts are edited by journalists who exercise significant power in terms of gatekeepers and opinion-leaders (Kjaer \& Slaatta, 2007). Thus, the actual legitimation arguments unavoidably reflect the values and practices of Finnish business journalists_ — and their preferences in terms of what they think would appeal to the Finnish audience. From this perspective, the legitimation texts can be seen as co-authored productions that express the Finnish perspective and even Finnish nationalism. It would therefore be very interesting to compare these texts with the media coverage in Uruguay, Argentina, or Spain.

\section{Acknowledgements}

Financial support for this project was provided by The Foundation for Economic Education and The Marcus Wallenberg Foundation in Finland. We are grateful to the associate editor Robyn Thomas, the anonymous SJM reviewers, Guido Palazzo, and the participants of the Sub-theme 16 (The Changing Role and Responsibility of Business in the Global Society) at 
the 23rd EGOS (European Group for Organizational Studies) Colloquium 2007 in Vienna, for their insightful comments on earlier versions of this paper.

\section{References}

Alvarez, J. L., Mazza, C., \& Pedersen, J. S. (2005). Editorial: The role of mass media in the consumption of management knowledge. Scandinavian Journal of Management, 21, 127132.

Alvesson, M., \& Kärreman, D. (2000). Taking the linguistic turn in organizational research: Challenges, responses, consequences. The Journal of Applied Behavioral Science, 36(2), $136-158$.

Ashforth, B. E., \& Gibbs, B. W. (1990). The double-edge of organizational legitimation. Organization Science, 1(2), 177-194.

Bansal, P., \& Clelland, I. (2004). Talking trash: Legitimacy, impression management, and unsystematic risk in the context of the natural environment. Academy of Management Journal, 47(1), 93-103.

Bansal, P., \& Roth, K. (2000). Why companies go green: A model of ecological responsiveness. Academy of Management Journal, 43(4), 717-736.

Basu, K., \& Palazzo, G. (2008). Corporate social responsibility: A process model of sensemaking. Academy of Management Review, 33(1), 122-136.

Bauman, Z., \& May, T. (2001). Thinking sociologically. Oxford: Blackwell. Berger, P. L., \& Luckmann, T. (1966). The social construction of reality: A treatise in the sociology of knowledge. New York: Anchor Books/Doubleday.

Calton, J. M., \& Payne, S. L. (2003). Coping with paradox: Multistakeholder learning dialogue as a pluralist sensemaking process for addressing messy problems. Business and Society, 42(1), $7-42$.

Campbell, D. (2000). Legitimacy theory or managerial reality construction? Corporate social disclosure in Marks \& Spencer plc corporate reports 1969-1997. Accounting Forum, 24(1), $80-100$. 
Chouliaraki, L., \& Fairclough, N. (1999). Discourse in late modernity: Rethinking critical discourse analysis. Edinburgh: Edinburgh University Press.

Coupland, C. (2005). Corporate social responsibility as argument on the web. Journal of Business Ethics, 62, 355-366.

Coupland, C. (2006). Corporate social and environmental responsibility in web-based reports: Currency in the banking sector? Critical Perspectives on Accounting, 17, 865-881.

Creed, D., Scully, M., \& Austin, J. (2002). Clothes make the person? The tailoring of legitimating accounts and the social construction of identity. Organization Science, 13, 475496.

De Blasio, G. G. (2007). Coffee as a medium for ethical, social, and political messages: Organizational legitimacy and communication. Journal of Business Ethics, 72, 47-59.

Deegan, C. (2002). Introduction: The legitimising effect of social and environmental disclosures-A theoretical foundation. Accounting, Auditing \& Accountability Journal, 15(3), $282-311$.

Deegan, C., Rankin, M., \& Tobin, J. (2002). An examination of the corporate social and environmental disclosures of BHP from 1983-1997: A test of legitimacy theory. Accounting, Auditing \& Accountability Journal, 15(3), 312-332.

Deephouse, D. L. (1996). Does isomorphism legitimate? Academy of Management Journal, 39(4), 1024-1039.

Deephouse, D. L., \& Suchman, M. (2008). Legitimacy in organizational institutionalism. In R. Greenwood, C. Oliver, R. Suddaby, \& K. Sahlin (Eds.), The Sage handbook of organizational institutionalism (pp. 49-77). Thousand Oaks, CA: Sage.

DiMaggio, P. J., \& Powell, W. W. (1983). The iron cage revisited: Institutional isomorphism and collective rationality in organizational fields. American Sociological Review, 48, 147160.

Dowling, J., \& Pfeffer, J. (1975). Organizational legitimacy: Social values and organizational behavior. Pacific Sociological Review, 18, 122-136. 
Driscoll, C. (2006). The not so clear-cut nature of organizational legitimating mechanisms in the Canadian forest sector. Business \& Society, 45(3), 322-353.

Fairclough, N. (1992). Discourse and social change. Cambridge: Polity Press.

Fairclough, N. (1995a). Media discourse. London: Edward Arnold.

Fairclough, N. (1995b). Critical discourse analysis: The critical study of language. London: Longman.

Fairclough, N. (2005). Discourse analysis in organization studies: The case for critical realism. Organization Studies, 26(6), 915-939.

Giddens, A. (1984). The constitution of society. Cambridge, UK: Polity Press.

Hunter, T., \& Bansal, P. (2007). How standard is standardized MNC global environmental communication? Journal of Business Ethics, 71, 135-147.

Hybels, R. C. (1995). On legitimacy, legitimation, and organizations: A critical review and integrative theoretical model. Academy of Management Proceedings, 241-245.

Joutsenvirta, M. (2006). Ympa “risto“keskustelun yhteiset arvot: Diskurssianalyysi Enson ja Greenpeacen ympa risto"kirjoituksista [The shared values of the environmental debate: Discourse analysis of Enso's and Greenpeace's environmental writings]. Doctoral dissertation, Publications of the Helsinki School of Economics, A 273, Helsinki (in Finnish).

Joutsenvirta, M. (in press). A language perspective to environmental management and corporate responsibility. Business Strategy and the Environment, doi:10.1002/bse.574.

Kjaer, P., \& Slaatta, T. (2007). Mediating business: The expansion of business journalism. Copenhagen: Copenhagen Business School Press.

Kostova, T., \& Zaheer, S. (1999). Organizational legitimacy under conditions of complexity: The case of the multinational enterprise. Academy of Management Review, 24(1), 64-81.

Lawrence, T. B., Phillips, N., \& Hardy, C. (1999). Watching whale watching: Exploring the discursive foundations of collaborative relationships. Journal of Applied Behavioral Science, $35(4), 479-502$. 
Levy, D. L. (2008). Political contestation in global production networks. Academy of Management Review, 33(4), 943-963.

Livesey, S. M. (2001). Eco-identity as discursive struggle: Royal Dutch/Shell, Brent Spar, and Nigeria. The Journal of Business Communication, 38(1), 58-91.

Livesey, S. M. (2002). The discourse of the middle ground: Citizen Shell commits to sustainable development. Management Communication Quarterly, 15(3), 313-349.

Livesey, S. M., \& Kearins, K. (2002). Transparent and caring corporations? Organization \& Environment, 15(3), 233-258.

Long, B. S., \& Driscoll, C. (2008). Codes of ethics and the pursuit of organizational legitimacy: Theoretical and empirical contributions. Journal of Business Ethics, 77, 173189.

Margolis, J. D., \& Walsh, J. P. (2003). Misery loves companies: Rethinking social initiatives by business. Administrative Science Quarterly, 48, 268-305.

Marsden, C. (2000). The new corporate citizenship of big business: Part of the solution to sustainability? Business and Society Review, 105(1), 9-25.

Matten, D., \& Crane, A. (2005). Corporate citizenship: Toward an extended theoretical conceptualization. Academy of Management Review, 30(1), 166-179.

Matten, D., Crane, A., \& Chapple, W. (2003). Behind the mask: Revealing the true face of corporate citizenship. Journal of Business Ethics, 45, 109-120.

Meyer, J. W., \& Rowan, B. (1977). Institutionalized organizations: Formal structure as myth and ceremony. American Journal of Sociology, 83, 340-363.

Discursive (de)legitimation of a contested Finnish greenfield investment project in Latin America 95

Milne, M. J., \& Patten, D. M. (2002). Securing organizational legitimacy: An experimental decision case examining the impact of environmental disclosures. Accounting, Auditing, and Accountability Journal, 15(3), 372—406. 
Mirvis, P. H. (2000). Transformation at Shell: Commerce and citizenship. Business and Society Review, 105(1), 63-84.

Morsing, M., \& Schultz, M. (2006). Corporate social responsibility communication: Stakeholder information, response and involvement strategies. Business Ethics: A European Review, 15(4), 323-338.

O'Donovan, G. (2002). Environmental disclosures in the annual report: Extending the applicability and predictive power of legitimacy theory. Accounting, Auditing \& Accountability Journal, 15(3), 344-371.

O’Dwyer, B. (2002). Managerial perceptions of corporate social disclosure: An Irish story. Accounting, Auditing \& Accountability Journal, 15(3), 406-436.

Palazzo, G., \& Scherer, A. G. (2006). Corporate legitimacy as deliberation: A communicative framework. Journal of Business Ethics, 66, 71-88.

Parsons, T. (1960). Structure and process in modern society. Glencoe, IL: Free Press.

Patten, D. (1992). Intra-industry environmental disclosures in response to the Alaskan oil spill: A note on legitimacy theory. Accounting, Organizations and Society, 17(5), 471 475.

Pfeffer, J., \& Salancik, G. R. (1978). The external control of organizations: A resource dependence perspective. New York, NY: Harper and Row.

Phillips, N., Lawrence, T. B., \& Hardy, C. (2004). Discourse and institutions. Academy of Management Review, 29(4), 635-652.

Potter, J., \& Wetherell, M. (1987). Discourse and social psychology: Beyond attitudes and behaviour. London: Sage.

Rojo, L., \& Van Dijk, T. (1997). There was a problem, and it was solved!: Legitimating the expulsion of 'illegal' migrants in Spanish parliamentary discourse Discourse \& Society, 8, $523-566$.

Ruef, M., \& Scott, W. R. (1998). A multidimensional model of organizational legitimacy: Hospital survival in changing institutional environments. Administrative Science Quarterly, $43,877-904$. 
Scherer, A. G., \& Palazzo, G. (2007). Toward a political conception of corporate responsibility: Business and society seen from a Habermasian perspective. Academy of Management Review, 32(4), 1096-1120.

Scherer, A. G., Palazzo, G., \& Baumann, D. (2006). Global rules and private actors: Toward a new role of the transnational corporation in global governance. Business Ethics Quarterly, $16(4), 505-532$.

Scott, W. R. (1995). Institutions and organizations. Thousand Oaks, CA: Sage.

Sethi, S. P. (1975). Dimensions of corporate social performance: An analytical framework. California Management Review, 17(3), 58-64.

Sethi, S. P. (2002). Standards for corporate conduct in the international arena: Challenges and opportunities for multinational corporations. Business and Society Review, 107, 20—40.

Silverman, D. (1993). Interpreting qualitative data: Methods for analysing talk, text and interaction. London: Sage.

Spar, D. L., \& La Mure, L. T. (2003). The power of activism: Assessing the impact of NGOs on global business. California Management Review, 45(3), 78-101.

Suchman, M. C. (1995). Managing legitimacy: Strategic and institutional approaches. Academy of Management Review, 20(3), 571-610.

Suddaby, R., \& Greenwood, R. (2005). Rhetorical strategies of legitimacy. Administrative Science Quarterly, 50, 35-67.

Swanson, D. L. (1999). Towards an integrative theory of business and society: A research strategy for corporate social performance. Academy of Management Review, 24(3), 506521.

Tregidga, H., \& Milne, M. J. (2006). From sustainable management to sustainable development: A longitudinal analysis of a leading New Zealand environmental reporter. Business Strategy and the Environment, 15, 219-241.

Vaara, E., \& Tienari, J. (2008). A discursive perspective on legitimation strategies in multinational corporations. Academy of Management Review, 33(4), 985-993. 
Vaara, E., Tienari, J., \& Laurila, J. (2006). Pulp and paper fiction: On the discursive legitimation of global industrial restructuring. Organization Studies, 27(6), 789-810.

Van Dijk, T. A. (1993). Principles of critical discourse analysis. Discourse and Society, 8, $5-6$.

Weber, M. (1968). Economy and society: An interpretative sociology. New York: Bedminister Press.

Williamson, H. (2008). Crossed lines between Germany and Finland Nokia is accused of mishandling a factory closure in Bochum. Financial Times, May 14, p. 14.

Wood, D. J. (1991). Corporate social performance revisited. Academy of Management Review, 16, 691-718.

Yearley, S. (1991). The green case: A sociology of environmental issues, arguments and politics. London: Harper Collins. 